\title{
Perceptions of free enterprise and business - an examination of the status quo in South Africa
}

\author{
M.E. Nasser \\ School of Business Leadership, University of South Africa, Pretoria
}

\begin{abstract}
Management has always contended that corporate employees have a very limited knowledge regarding the free enterprise and hence business system. The consequences of such a lack of understanding have always been apparent - worker dissatisfactions, labour unrest, conflict, and decreased productivity. This study is the first attempt to quantify the exact extent of this non-understanding among corporate employees in South Africa. This study has examined scientifically, via very extensive field work in 78 medium to large organizations situated in the PWV, western- and eastern Cape, and Natal regions, the perceptions of some 3723 employees regarding business in South Africa. The analysis which covers six major categcries of business comprehension, separated by education, position in the hierarchy, years of service, income level, sector, and race, provides very worrying evidence of the depth of the problem. The concomitant impacts accompanying the problem are also sketched so that management might better understand the nature and extent of the problems facing business in South Africa. S. Afr. J. Bus. Mgmt. 1985, 16: 1-6
\end{abstract}

\footnotetext{
Bestuur het nog altyd beweer dat maatskappywerknemers 'n baie beperkte kennis van die vryemarkstelsel en dus ook van besigheid het. Die gevolge van só 'n gebrek aan insig was duidelik - werknemerontevredenheid, arbeidsoproerigheid, konflik en dalende produktiwiteit. Hierdie studie is die eerste poging om die presiese omvang van hierdie gebrek aan insig onder maatskappywerknemers in Suid-Afrika te bepaal. Deur middel van uitgebreide veldwerk in 78 middel. tot groot organisasies in die PWV., Weskaap-, Ooskaap-en Natal-gebiede is die waarnemings van sowat 3723 werknemers betreffende die bedryfslewe wetenskaplik ondersoek. Die ontleding van ses hoofkategorieë wat bedryfsbegrip omvat, onderverdeel in opleiding, posisie in die hiërargie, aantal diensjare, inkomstevlak, sektor en ras, verskaf kommerwekkende bewyse van die diepte van die probleem. Die gepaardgaande indrukke word ook geskets sodat bestuur die aard en omvang van die probleme wat die Suid-Afrikaanse bedryfslewe in die gesig staar, beter kan begryp.

S.-Afr. Tydskr. Bedryfsl. 1985, 16: 1-6
}

\section{M.E. Nasser}

School of Business Leadership, University of South Africa, P.O. Box 392, Pretoria, 0001 Republic of South Africa

Accepted October 1984
It has long been contended that corporate employees in South Africa have, at best, a very limited understanding of the 'free enterprise' and hence business system. Management has furthermore recognized that a full and meaningful contribution by the workforce is only possible if employees understand both the basic construct of the business system and the rewards which such a system can provide for them. There is much research and experiential evidence to indicate that the less the understanding of the organization and its functions in relation to the individual employee and his own welfare and needs, the greater the potential level of dissatisfaction, conflict and decreased productivity will be within those organizations.

What has been absent to date is quantified evidence regarding the nature and extent of this non-understanding as well as the exact impact of these perceptions on employee and hence corporate performance. This study has attempted to transcend these barriers by quantifying, for the first time, the perceptions corporate employees have of the business system in South Africa. Simultaneously this study has attempted to sketch the kind of impacts which emanate from such perceptions at all levels of the corporate hierarchy. An honest scientific attempt to examine a critical problem in micro detail is provided, so that management may more clearly understand both the nature and extent of employee perceptions facing business in South Africa.

\section{The study}

This study, as its title suggests, examines employee comprehension of the business system with the express purpose of identifying those areas of ignorance which negatively affect corporate performance. To this end, the comprehension of business and free-enterprise concepts among corporate employees in South Africa was tested by means of a questionnaire, personal interviews, and discussions. The questionnaire was constructed via a number of think-tank and Delphi exercises which generated 147 factors, 37 of which were selected for inclusion in the study. These 37 factors, in turn, were clustered into a number of specific categories, relating to the comprehension of business, namely:

- Critical steps in establishing a company

- Running expenses of a business

- On-going financing of a business

- Formulae for achieving improved productivity

- Sources for obtaining improved wages, and

- Distribution of post-tax company profits.

The respondent was asked to distribute a $100 \%$ total score amongst the factors which constituted the basic ingredients 
of the categories examined. For example, concerning 'Critical steps in establishing a company', the respondent was asked to distribute a $100 \%$ total score amongst the eight factors (ranging from building a factory through to buying machines) according to the importance he attached to each factor. The individual percentages for particular items were subsequently totalled and a weighted average percentage was calculated for the various sub-samples.

Of the original 3723 questionnaires which were either handed out in group sessions (with respect to literate respondents) or completed in interview sessions (in the case of illiterate respondents), $76 \%$ were sufficiently completed to be used in the analyses of the data. The respondents were employed by 78 organizations, each with labour complements of 100 people or more, and situated in the PWV triangle, the western and eastern Cape, and Natal. These organizations were, moreover, spread throughout the major economic sectors.

In the analyses of the data, the respondents were grouped according to a number of variables, namely educational and occupational status, length of service, income, economic sector of employment, and race. It is obvious that many of these variables are interlinked. For example, as higher education in South Africa has always been monopolized by Whites, it is obvious that Whites, relative to Blacks, will possess higher educational standards and, consequently, occupy higher occupational positions and earn higher incomes. Thus, a certain interdependency exists amongst the variables of race, education, occupational status, and income. Moreover, as a major number of African workers are employed in a migrantlabour capacity, one can expect their length of service with particular employers to be, on average, shorter than that of the remaining population groups. However, since length of service is, on a general level, unrelated to variables such as educational and occupational status, income, and race one can anticipare fewer significant differences between the various categories of respondents representing these variables when compared with the differences between the various categories contained within the other variables mentioned.

\section{The findings}

The data and the findings presented below are discussed according to a number of issues which were identified as relevant during the Delphi-sessions. The findings on each of these issues are presented in a logical sequence ranging from the establishing of a company through to the distribution of positax company profits.

\section{Critical steps in establishing a company}

Perueptions of the critical steps in establishing a company were analysed according to educational level (Table 1).

From the findings it is clear that the level of exposure to
Table 1 Critical steps in establishing a company according to educational level

\begin{tabular}{lcccc}
\hline & $\begin{array}{c}\text { Less than } \\
\text { std 6 } 6 \\
\%\end{array}$ & $\begin{array}{c}\text { Std 6- } \\
\text { std 8 } \\
\%\end{array}$ & $\begin{array}{c}\text { Std 9- } \\
\text { matric } \\
\%\end{array}$ & $\begin{array}{c}\text { Post- } \\
\text { matric } \\
\%\end{array}$ \\
\hline Building a factory & 43 & 23 & 10 & 6 \\
Government permission & 25 & 18 & 9 & 3 \\
Determining market & 11 & 19 & 14 & 16 \\
Obtaining money & 6 & 20 & 24 & 27 \\
Buying raw materials & 4 & 4 & 18 & 16 \\
Advertising & 1 & 5 & 8 & 8 \\
Hiring workers & 7 & 4 & 6 & 9 \\
Buying machines & 3 & 7 & 11 & 15 \\
\hline
\end{tabular}

business via the medium of education drastically affects the way an individual perceives priorities about establishing a new venture. While, for example, the financial dimension is of little significance to the respondent with less than a high school education, this dimension enjoys top priority amongst those respondents who possess matriculation or more. Of interest also, is the fact that physical facilities are of highest priority to those respondents with little formal education whereas this factor becomes increasingly less important as one moves up the educational ladder.

Perceptions regarding what is required to establish a new company thus vary substantially according to educational exposure and, hence, according to race. One of the main questions arising from such perceptual differences, concerns the impact that such differing perceptions may have on organizational functioning and efficiency.

\section{Running expenses of a business}

Perceptions of the running expenses of a business were analysed according to both educational (Table 2) and occupational level (Table 3).

Table 2 Running expenses of a business according to educational level

\begin{tabular}{lrrrr}
\hline & $\begin{array}{c}\text { Less than } \\
\text { std } 6 \\
\sigma_{0}\end{array}$ & $\begin{array}{c}\text { Std 6- } \\
\text { std } 8 \\
\%\end{array}$ & $\begin{array}{c}\text { Std 9- } \\
\text { matric } \\
\%\end{array}$ & $\begin{array}{c}\text { Post- } \\
\text { matric } \\
\%\end{array}$ \\
\hline Repaying loans & 10 & 14 & 18 & 23 \\
Raw materials & 8 & 8 & 11 & 13 \\
Government Tax & 21 & 17 & 12 & 10 \\
Employees' salaries & 4 & 6 & 14 & 18 \\
Managers salaries & 56 & 51 & 37 & 26 \\
Machinery and Plant & 1 & 4 & 8 & 10 \\
\hline
\end{tabular}

Table 3 Running expenses of a business according to occupational level

\begin{tabular}{|c|c|c|c|c|c|}
\hline Factor & $\begin{array}{l}\text { U'nskilked } \\
\text { workers } \\
\end{array}$ & $\begin{array}{c}\text { Semi-skilked } \\
\text { norkers } \\
\sigma_{0}\end{array}$ & $\begin{array}{c}\text { Skilked } \\
\text { workers } \\
\sigma_{\bullet}\end{array}$ & $\begin{array}{c}\text { Supervisory } \\
\text { management } \\
\sigma_{0}\end{array}$ & $\begin{array}{l}\text { Middle- to senior } \\
\text { management } \\
\sigma_{0}\end{array}$ \\
\hline Repaying laans & 14 & 18 & 16 & 6 & 7 \\
\hline Rau materials & 10 & 13 & 23 & 21 & 20 \\
\hline Government Tax & 14 & 20 & 19 & 14 & 12 \\
\hline Employes: salaries & 9 & 8 & 13 & 27 & 28 \\
\hline Mlanagers" sataries & 49 & 35 & 26 & 18 & 15 \\
\hline Mlachinen and Ptant & 4 & 6 & 3 & 14 & 18 \\
\hline
\end{tabular}


Concerning the running expenses of a business as perceived by educational level, the most noticeable changes occur in the ratios of total corporate expenditure allocated to managers $v i s-a$-vis employees' salaries. Whereas the respondents with a low level of education perceive an inordinately large amount of corporate money being spent on managerial salaries, the perceptions of the group with post-matriculation qualifications are more realistic. The perceptions of the lower educational group do, however, give cause for concern in view of the potential for industrial unrest inherent in perceptions such as these.

Concerning occupational status, it is apparent that as individual involvement with, and commitment to, the organization increase, perceptions regarding corporate life in general and the way in which a company is organized in particular, become more realistic.

Thus to prevent acute industrial unrest caused by gross misunderstanding of the corporate remuneration policy, organizations must attempt to formulate appropriate educational strategies relating to the realities of corporate finance distribution for the labour component.

\section{On-going financing of a business}

Perceptions of the on-going financing of a business were analysed according to both length of service (Table 4) and occupational level (Table 5).

It would appear that length of service, which may in turn

Table 4 On-going financing of a business according to length of service

\begin{tabular}{lrrrrrr}
\hline & \multicolumn{2}{l}{ Less } & & & \\
& than & $1-2$ & $2-3$ & $3-5$ & $5-10$ & $10+$ \\
Factor & $\begin{array}{c}\text { year } \\
\%\end{array}$ & $\begin{array}{c}\text { years } \\
\%\end{array}$ & $\begin{array}{c}\text { years } \\
\%\end{array}$ & $\begin{array}{c}\text { years } \\
\%\end{array}$ & $\begin{array}{c}\text { years } \\
\%\end{array}$ & $\begin{array}{c}\text { years } \\
\%\end{array}$ \\
\hline Bank financing & 42 & 42 & 31 & 30 & 27 & 26 \\
Past profits & 2 & 4 & 5 & 8 & 18 & 18 \\
Own funds & 18 & 16 & 18 & 18 & 20 & 21 \\
Government financing & 31 & 28 & 21 & 12 & 4 & 3 \\
Sales & 7 & 10 & 25 & 32 & 31 & 32 \\
\hline
\end{tabular}

provide some indication of years of experience, is directly related to employee perceptions of company financing. This correlation may say something about employee orientation and exposure to the realities of organizational life. While it could be argued that knowledge about the source of business financing does not constitute an essential prerequisite for satisfactory task performance, it must, at the same time, be remembered that misconceptions can lead to warped attitudes and low motivation. Thus, while bank and government financing are perceived to be important sources of finance by those respondents with less than three years service, the significance of sales and past profits becomes most apparent amongst the group which has service levels of three years or more. Such perceptions must affect productivity and hence final corporate results.

Turning to occupational status, the lower occupational levels and, in particular, the predominantly Black unskilled and semi-skilled workers believe that the major sources of corporate financing are external to the corporation. For those respondents who occupy supervisory and middle- to senior management positions, the converse holds true - in other words, the emphasis is placed on internal factors such as sales and past profits.

It would thus appear that a direct relationship exists between years of service, occupational level and the accuracy of perceptions regarding the on-going financing of a business. The lower the job category and the shorter the number of years of service, the more unrealistic will the perceptions regarding on-going corporate financing be.

\section{Formulae for achieving improved productivity}

Perceptions about formulae for achieving improved productivity were analysed according to income (Table 6). It was found that as earning capacity improves priorities for achieving improved productivity change as well.

While the predominantly Black low-income group are more concerned with salaries and training as the major mechanisms for obtaining improved productivity, the better paid supervisory and managerial groups balance their priorities by emphasizing staff motivation and improved technology to best tap the available resources of the company. A substantial

Table 5 On-going financing of a business according to occupational level

\begin{tabular}{lccccc}
\hline Factor & $\begin{array}{c}\text { Unskilled } \\
\text { workers } \\
\mathbf{\%}\end{array}$ & $\begin{array}{c}\text { Semi-skilled } \\
\text { workers } \\
\%\end{array}$ & $\begin{array}{c}\text { Skilled } \\
\text { workers } \\
\%\end{array}$ & $\begin{array}{c}\text { Supervisory } \\
\text { management } \\
\%\end{array}$ & $\begin{array}{c}\text { Middle- to senior } \\
\text { management } \\
\text { \% }\end{array}$ \\
\hline Bank financing & 49 & 40 & 30 & 35 & 22 \\
Past profits & 2 & 19 & 23 & 22 & 27 \\
Own funds & 15 & 15 & 15 & 12 & 8 \\
Government financing & 31 & 25 & 20 & 1 & 0 \\
Sales/Output & 3 & 1 & 12 & 30 & 43 \\
\hline
\end{tabular}

Table 6 Formulae for achieving improved productivity according to income

\begin{tabular}{|c|c|c|c|c|c|c|c|}
\hline Factor & $\begin{array}{c}\text { Less than R200 } \\
\text { per month } \\
\%\end{array}$ & $\frac{\text { R200 }- \text { R399 }}{\%}$ & $\begin{array}{c}\mathrm{R} 400-\mathrm{R} 699 \\
\%\end{array}$ & $\begin{array}{c}\mathrm{R} 700-\mathrm{R} 999 \\
\%_{0}\end{array}$ & $\begin{array}{c}\text { R1 } 000- \\
\text { R1 } 499 \\
\%\end{array}$ & $\begin{array}{c}\text { R1 } 500- \\
\text { R2 } 000 \\
\%\end{array}$ & $\begin{array}{c}\text { R2 } \\
\%\end{array}$ \\
\hline Better training & 42 & 42 & 46 & 40 & 36 & 30 & 28 \\
\hline More machines & 7 & 7 & 5 & 10 & 10 & 19 & 22 \\
\hline Longer hours & 9 & 13 & 8 & 15 & 9 & 8 & 8 \\
\hline Improved salaries & 39 & 36 & 37 & 29 & 27 & 25 & 21 \\
\hline Staff motivation & 3 & 2 & 4 & 6 & 18 & 18 & 21 \\
\hline
\end{tabular}


Table 7 Sources for obtaining improved wages according to occupational level

\begin{tabular}{lccccc}
\hline & $\begin{array}{c}\text { Unskilled } \\
\text { workers } \\
\%\end{array}$ & $\begin{array}{c}\text { Semi-skilled } \\
\text { workers } \\
\%\end{array}$ & $\begin{array}{c}\text { Skilled } \\
\text { workers } \\
\%\end{array}$ & $\begin{array}{c}\text { Supervisory } \\
\text { management } \\
\%\end{array}$ & $\begin{array}{c}\text { Middle- to senior } \\
\text { management } \\
\%\end{array}$ \\
\hline Factor & 17 & 11 & 32 & 39 & 46 \\
Improved sales/Production Output & 24 & 31 & 39 & 42 & 25 \\
Increased price of products & 29 & 27 & 14 & 6 & 0 \\
Financial loans & 30 & 29 & 11 & 2 & 4 \\
Pay Whites less & 0 & 2 & 4 & 11 & 25 \\
Employ fewer people & & &
\end{tabular}

perceptual gap exists between the various income levels. This gap is particularly obvious when comparing the managerial vis-á-vis the non-managerial staff. This problem in itself is cause for concern if organizations are to improve knowledge concerning the factors relating to improved productivity.

\section{Sources for obtaining improved wages}

Perceptions relating to the sources for obtaining improved wages were analysed according to occupational level (Table 7), length of service (Table 8), and economic sector (Table 9).

With respect to occupational level, the lower levels of the organizational hierarchy perceive improved wages to result from paying Whites less, increasing the price of product and borrowing externally. Little concern is expressed for employee numbers, improved sales, and productivity.

As the analysis moves through the middle- to senior groups on the organizational ladder, a substantial reorganization of priorities occurs. The sources for obtaining improved wages for this group are directly reflected in internal efficiencies; that is, in the decrease of the number of employees as the major mechanism for bringing about salary improvements.

Few significant differences emerged, with regard to length of service. This finding can be attributed to the fact that, apart from African migrant workers who tend to be employed on

Table 8 Sources for obtaining improved wages according to length of service

\begin{tabular}{|c|c|c|c|c|c|c|}
\hline Factor & $\begin{array}{l}\text { Less } \\
\text { than } \\
1 \text { year } \\
\%\end{array}$ & $\begin{array}{c}1-2 \\
\text { years } \\
\%\end{array}$ & $\begin{array}{c}2-3 \\
\text { years } \\
\%\end{array}$ & $\begin{array}{c}3-5 \\
\text { years } \\
\%\end{array}$ & $\begin{array}{c}5-10 \\
\text { years } \\
\%\end{array}$ & $\begin{array}{c}10+ \\
\text { years } \\
\%\end{array}$ \\
\hline \multicolumn{7}{|l|}{ Improved sales/ } \\
\hline Production output & 14 & 15 & 15 & 18 & 22 & 18 \\
\hline Increased price & & & & & & \\
\hline of products & 38 & 38 & 40 & 37 & 38 & 40 \\
\hline Financial loans & 21 & 21 & 21 & 20 & 25 & 24 \\
\hline Pay Whites less & 25 & 24 & 24 & 24 & 10 & 15 \\
\hline Employ fewer people & 2 & 2 & 0 & 1 & 5 & 3 \\
\hline
\end{tabular}

a temporary or short-term basis, length of service is not dependent on factors such as educational and occupational status, income, and race.

Concerning the economic sector, substantial differences exist between the perceptions of the respondents employed by organizations within the various economic sectors. This finding may reflect organizational cultures specific to particular economic sectors and tells us a great deal about the differing characteristics of employees within each of these sectors. Certainly, the Agriculture and Forestry sector, for example, presents an entirely different profile from the Finance and Insurance sector about the perceptions of the people they employ.

Employee perceptions toward sources of improved wages appear to be directly linked to the level the employee occupies within the organizational hierarchy. There are very significant differences between the perceptions of the predominantly Black unskilled workers on the one hand and those of the predominantly White managerial staff on the other. While the respondents lower down the hierarchy emphasized a racial redistribution of wages backed by external financial sources, the managerial group emphasized increased sales/production output and a reduction in the number of employees. Regarding the economic sector, perceptions reflect differences in both corporate culture and the characteristics of the employees found within the various economic sectors concerned.

For example, in sectors where a heavier concentration of Black employees are found (for example, in Mining and Agriculture), perceptions are heavily biased by the basic needs of these employees. The emphasis is on survival.

\section{Distribution of post-tax company profits}

Perceptions regarding the distribution of post-tax company profits were analysed according to educational (Table 10) and occupational (Table 12) status, income (Table 13), and race (Table 11).

Concerning educational level, a direct relationship emerged between educational level and accuracy of perceptions

Table 9 Sources for obtaining improved wages according to economic sector

\begin{tabular}{|c|c|c|c|c|c|c|c|}
\hline Factor & $\begin{array}{c}\text { Agriculture } \\
\text { \& Forestry } \\
\sigma_{0}\end{array}$ & $\begin{array}{c}\text { Construction } \\
\%\end{array}$ & $\begin{array}{c}\text { Finance and } \\
\text { insurance } \\
\%\end{array}$ & $\begin{array}{c}\text { Manufacturing } \\
\% \%\end{array}$ & $\underset{\%}{\operatorname{Mining}}$ & $\begin{array}{c}\text { Retailing } \\
\text { and hotels } \\
\% \%\end{array}$ & $\begin{array}{c}\text { Transport } \\
\%\end{array}$ \\
\hline \multicolumn{8}{|l|}{ Improved sales/ } \\
\hline Production output & 21 & 12 & 35 & 20 & 16 & 30 & 15 \\
\hline \multicolumn{8}{|l|}{$\begin{array}{l}\text { Increased price of } \\
\text { products/services }\end{array}$} \\
\hline Financial loans & $\begin{array}{l}20 \\
28\end{array}$ & $\begin{array}{r}8 \\
37\end{array}$ & 31 & 27 & 26 & 32 & 37 \\
\hline Pay Whites less & $\begin{array}{l}28 \\
13\end{array}$ & $\begin{array}{l}37 \\
39\end{array}$ & 7 & 21 & 31 & 17 & 32 \\
\hline Employ fewer people & $\begin{array}{r}13 \\
0\end{array}$ & 39 & 8 & 30 & 27 & 17 & 14 \\
\hline & 0 & 4 & 19 & 2 & 0 & 4 & 2 \\
\hline
\end{tabular}


regarding the distribution of post-tax company profits. Moreover, substantial differences in perceptions about the distribution of post-tax company profits between the various racial groups were also found to exist. While White employees appeared to have a reasonably positive perception of their own salaries and bonuses vis-a-vis the higher levels of management, the Black respondents perceive themselves as being grossly discriminated against concerning profit distribution.

Table 10 Distribution of post-tax company profits according to educational level

\begin{tabular}{lcccc}
\hline & $\begin{array}{c}\text { Less than } \\
\text { std } 6 \\
\%\end{array}$ & $\begin{array}{c}\text { Std 6- } \\
\text { Std } 8\end{array}$ & $\begin{array}{c}\text { Std 9- } \\
\text { matric } \\
\%\end{array}$ & $\begin{array}{c}\text { Post- } \\
\text { matric } \\
\%\end{array}$ \\
\hline $\begin{array}{l}\text { Factor } \\
\text { Malary increases }\end{array}$ & 76 & 71 & 56 & 19 \\
$\begin{array}{l}\text { Worker bonuses and } \\
\text { salary increases }\end{array}$ & 3 & 5 & 13 & 30 \\
$\begin{array}{l}\text { Financial and Capital } \\
\text { investments }\end{array}$ & 21 & 23 & 22 & 32 \\
\begin{tabular}{l} 
Shareholders payback \\
\hline
\end{tabular} & 0 & 1 & 9 & 19 \\
\hline
\end{tabular}

Table 11 Distribution of post-tax company profits according to race

\begin{tabular}{lccc}
\hline & $\begin{array}{c}\text { White } \\
\text { employees } \\
\%\end{array}$ & $\begin{array}{c}\text { African } \\
\text { employees } \\
\%\end{array}$ & $\begin{array}{c}\text { Asian and } \\
\text { coloured } \\
\text { employees } \\
\%\end{array}$ \\
\hline Factor & 27 & 69 & 58 \\
\hline $\begin{array}{l}\text { Management bonuses } \\
\text { and salary increases } \\
\begin{array}{l}\text { Worker bonuses and } \\
\text { salary increases }\end{array}\end{array}$ & 32 & 4 & 11 \\
$\begin{array}{l}\text { Financial and capital } \\
\text { investments }\end{array}$ & 38 & 27 & 30 \\
\begin{tabular}{l} 
Shareholders payback \\
\hline
\end{tabular} & 3 & 0 & 1 \\
\hline
\end{tabular}

Clearly, employee involvement in, and commitment to, the organization has a substantial impact on perceptions regarding the distribution of post-tax profits. Such perceptions, however, concern not only the distribution issues but also levels of inequality felt within South African organizations. Thus, while the non-managerial staff perceived management as receiving an inordinately large share of post-tax profits, the higher levels of management regarded the distribution of profits as far more equitable. This finding again emerges from the analyses according to income. In this instance, although the highincome earners were more realistic than the lower income earners regarding the distribution of post-tax profits, all groups appeared to feel that others were being treated better than themselves. It is also interesting to note that the shareholder was disregarded by the lower-income level. Although further research on this issue is indicated, it would appear from our findings that a tremendous ignorance exists amongst employees regarding the role and rights of the shareholder.

It is clear from this study that substantial differences in interpretation exist regarding the distribution of an organization's post-tax profits. The Black, lesseducated, unskilled, and semi-skilled workers who receive low wages perceive the distribution of post-tax profits in a way which suggests gross inequality between White managerial and Black non-managerial staff. Such perceptions - whether correct or incorrect - have serious implications for industrial relations. Moreover, the perceptions of the well-educated, high-income, high-status White managerial group, although in some ways more realistic, indicate substantial insensitivity to the plight of Black labour. Both groups perceive the other as receiving a greater share of post-tax profits than themselves. The findings do suggest that managerial staff may not be sufficiently sensitive to the problems being encountered by the non-managerial group. Although the latter may exaggerate the level of inequality which exists in the working environment, neither of these perceptions augur well for the cause of healthy industrial relations in this country.

Table 12 Distribution of post-tax company profits according to occupational level

\begin{tabular}{lccccc}
\hline & $\begin{array}{c}\text { Unskilled } \\
\text { workers } \\
\%\end{array}$ & $\begin{array}{c}\text { Semi-skilled } \\
\text { workers } \\
\%\end{array}$ & $\begin{array}{c}\text { Skilled } \\
\text { workers } \\
\%\end{array}$ & $\begin{array}{c}\text { Supervisory } \\
\text { management } \\
\%\end{array}$ & $\begin{array}{c}\text { Middle- to senior } \\
\text { management } \\
\%\end{array}$ \\
\hline Factor & 72 & 53 & 48 & 21 & 17 \\
\hline $\begin{array}{l}\text { Management bonuses } \\
\text { and salary increases }\end{array}$ & 3 & 9 & 12 & 39 & 30 \\
$\begin{array}{l}\text { Worker bonuses and } \\
\text { salary increases }\end{array}$ & 25 & 38 & 37 & 31 & 35 \\
$\begin{array}{l}\text { Financial and capital } \\
\text { investment }\end{array}$ & 0 & 0 & 3 & 9 & 18 \\
\begin{tabular}{l} 
Shareholders payback \\
\hline
\end{tabular} & & & & & \\
\hline
\end{tabular}

Table 13 Distribution of post-tax company profits according to income

\begin{tabular}{|c|c|c|c|c|c|c|c|}
\hline Factor & $\begin{array}{c}\text { Less than } \\
\text { R200 per month } \\
\% \%\end{array}$ & $\begin{array}{c}\mathbf{R} 200-\mathrm{R} 399 \\
\%\end{array}$ & $\underset{\%}{\mathrm{R} 400-\mathrm{R} 699}$ & $\begin{array}{c}\mathrm{R} 700-\mathrm{R} 999 \\
\%\end{array}$ & $\begin{array}{c}\text { R1 } 000- \\
\text { R1 } 499 \\
\%\end{array}$ & $\begin{array}{c}\mathrm{R} 1500 \\
\mathrm{R} 2000 \\
\%\end{array}$ & $\mathrm{R} 2 \underset{\%}{000+}$ \\
\hline $\begin{array}{l}\text { Management bonuses } \\
\text { and salary increases }\end{array}$ & 85 & 83 & 76 & 72 & 31 & 23 & 8 \\
\hline $\begin{array}{l}\text { Worker bonuses and } \\
\text { salary increases }\end{array}$ & 1 & 2 & 4 & 12 & 33 & 32 & 44 \\
\hline $\begin{array}{l}\text { Financial and capital } \\
\text { investments }\end{array}$ & 14 & 15 & 20 & 14 & 7 & 23 & 22 \\
\hline Shareholders payback & 0 & 0 & 0 & 2 & 29 & 22 & 26 \\
\hline
\end{tabular}




\section{Conclusion}

These conclusions speak for themselves: It would appear that a great deal of ignorance about business and free enterprise exists among corporate employees in South Africa. Such ignorance is particularly predominant amongst the less-educated, unskilled, and semi-skilled workers. These workers regard themselves as grossly discriminated against in terms of remuneration and perceive the free enterprise system as a system which is beneficial solely to the White managerial staff. Such perceptions of gross inequality - whether correct or incorrect - do not augur well for the future of industrial relations in this country. Companies must, therefore, take stock of this situation and attempt to move towards the creation of greater com- mitment to, and involvement in their structures by their non-managerial work-forces. Such involvement and commitment can, however, only be achieved via an increased comprehension of business and free enterprise concepts amongst corporate employees and a fairer distribution of rewards within the corporate setting. In other words, the removal of discrimination should not only be seen as part of an on-going corporate philosophy but should rather be recognized as an immediate priority for corporate action. Such a sense of urgency will ensure the type of corporate climate which makes for high levels of commitment to corporate objectives and will consequently ensure the continued survival and growth of a genuine free enterprise and business system in South Africa. 